\title{
NICOLE Institutional Theories and International Development
}

\begin{abstract}
A recent trend in international development circles is 'New Institutionalism'. In a slogan, the idea is just that good institutions matter. The slogan itself is so innocuous as to be hardly worth comment. But the push to improve institutional quality has the potential to have a much less innocuous impact on aid efforts and other aspects of international development. This paper provides a critical introduction to some of the literature on institutional quality. It looks, in particular, at an argument for the conclusion that making aid conditional on good institutional quality will promote development by reducing poverty. This paper suggests that there is little theoretical or empirical evidence that this kind of conditionality is good for the poor.
\end{abstract}

Keywords: Institutions, Aid, Conditionality, International Development

\section{Introduction}

A recent trend in international development circles is 'New Institutionalism'. In a slogan, the idea is just that good institutions matter. The slogan itself is so innocuous as to be hardly worth comment. But the push to improve institutional quality has the potential to have a much less innocuous impact on aid efforts and other aspects of international development. This paper provides a critical introduction to some of this literature. It looks, in particular, at an argument for the conclusion that making aid conditional on good institutional quality will promote development by reducing poverty. This paper suggests that there is little theoretical or empirical evidence that this kind of conditionality is good for the poor. It also raises what may be a general problem for theoretical economic arguments based on posited incentive effects. Such arguments require empirical substantiation (which many argue requires some previously substantiated theoretical framework). In making its case, this paper has the subsidiary aim of showing how philosophers can contribute to a largely neglected area of study. Most work in the philosophy of economics looks at the foundations of game theory and welfare economics. Philosophers have paid very little attention to public and development economics. ${ }^{1}$ There are many important policy arguments that desperately require analytic examination of the sort philosophers are well placed to offer. ${ }^{2}$ The next section explains the kind of

1 There are, of course, some exceptions. See, for instance, Gillian Brock, Global Justice: A Cosmopolitan Account (Oxford: Oxford University Press, 2009); Nicole Hassoun, Globalization and Global Justice: Shrinking Distance, Expanding Obligations (Cambridge University Press: 2012); Leif Wenar, 'Property Rights and the Resource Curse', Philosophy \& Public Affairs 36/1 (2008), 2-32. For discussion of philosophical work in the public economics literature see, for instance, Subbu Subramanian, 'Counting the Poor: An Elementary Difficulty in the Measurement of Poverty', Economics and Philosophy 18 (2002), 277-85.

2 For examples, see ibid. 
international development at issue in this paper and motivates the inquiry into New Institutional arguments about international aid. The section 'Theoretical Arguments for Conditionality: Moral Hazard' considers the main theoretical argument for making aid conditional on institutional quality. The section 'The Empirical Evidence and Critique' considers the empirical evidence that might support such conditionality. The last section concludes.

\section{New Institutionalism and International Aid}

There is no single definition of international development in the literature, but it is almost uncontroversial to suppose that whatever else good development requires, it requires poverty reduction. ${ }^{3}$ Perhaps one of the most comprehensive practical accounts of international development is embodied in the Millennium Development Goals (MDGs). The MDGs have served to coordinate the efforts of many different actors and provide one broadly compelling picture of what good development requires (or at least some conditions for good development). The first MDG is to reduce poverty. In recent discussions of, and resolutions regarding, the global development agenda post-2015, poverty reduction remains a clear focus. ${ }^{4}$ So, this paper will assume that good development is not just a matter of fostering growth. Rather, good development (and international aid that promotes development) should, at a minimum, help the poor. A lot of the philosophical work on international development would support this contention. ${ }^{5}$

Similarly, when one pays attention to the details of the regressions in economists' empirical studies, it is clear that they contain many different and inconsistent (implicit) definitions of 'institutional quality'. Some focus on relatively stable features of countries that persist over time and others focus more on the current policy environment. A cynic might even suggest that the 'new' focus on institutional quality is not new at all. Rather it allows economists to repackage old results under a new label - looking at 'good' policies like trade liberalization,

3 Further, there is reason to believe that aiding countries and institutions are often committed to reducing poverty with their aid. The World Bank, for instance, bills itself as an institution deeply concerned about poverty and does not articulate or defend an alternate moral framework. The Bank says: 'Our mission is to fight poverty with passion and professionalism for lasting results and to help people help themselves and their environment by providing resources, sharing knowledge, building capacity and forging partnerships in the public and private sectors' (World Bank, 'About Us', [2013], http://www.worldbank.org/en/about [accessed 20 August 2013]). The International Development Association (IDA) website says: 'The International Development Association (IDA) is the World Bank's fund for the poorest countries' (IDA, 'What is IDA?', [2013], http://www.worldbank.org/ida/ [accessed 20 June 2013]).

4 United Nations, 'United Nations A/RES/65/1', (October 19, 2010), www.un.org/en/mdg/summit2010/pdf/outcome_ documentN1051260.pdf (accessed 20 June 2013).

5 Peter Singer, 'Famine Affluence and Morality', Philosophy and Public Affairs 1/1 (1972), 229-43; Onora O'Neill, Faces of Hunger: An Essay on Poverty, Justice and Development (London: Allen and Unwin, 1986); Amartya Sen, Development as Freedom (New York: Anchor Books, 1999); Martha Nussbaum, Women and Human Development: The Capabilities Approach (Cambridge: Cambridge University Press, 2000); Thomas Pogge, 'Severe Poverty as a Human Rights Violation', in Thomas Pogge (ed.) Freedom from Poverty as a Human Right: Who Owes What to the Very Poor? (Oxford: Oxford University Press, 2005), 11-53; David Crocker, The Ethics of Global Development: Agency, Capability, and Deliberative Democracy (Cambridge: Cambridge University Press, 2008). 
corruption, and so forth and then calling these 'institutions' and concluding that good institutions are important. This paper will, thus, suppose that institutional quality is a cluster concept and pay attention to the details of each study which argues that it is important to give aid to countries with good institutions.

Despite the fact that there are different conceptions of institutional quality in the literature, the new focus on institutional quality's impact on aid may have a large impact on international development via its impact on poverty (and perhaps other things). Many countries and international institutions, including the World Bank, African Development Bank (ADB), the United Kingdom, and Canada use formulas for distributing aid that take into account institutional quality. ${ }^{6}$ More precisely, many states and international institutions use algorithms governing the amount of aid they offer to different countries that include some version of the World Bank's Country Policy and Institutional Assessment (CPIA) index - a measure of institutional quality. ${ }^{7}$ Some of these measures are quite complicated but many, like the CPIA, consider countries' economic, structural, social, and public sector policies (see the Appendix for further explanation of the CPIA, in particular). Consider the potential impact of World Bank aid alone. The International Development Association (IDA) is the part of the World Bank that helps the world's poorest people, 1.5 billion of whom live on less than the equivalent of $\$ 2$ a day. In 2008, the IDA gave Official Development Assistance (ODA) worth 6,689.24 million. ${ }^{8}$ It provides basic health services, primary education, clean water and sanitation, environmental protection, business support, infrastructure, and help with institutional reforms. ${ }^{9}$ So it really matters how this institution distributes its aid. Insofar as the concern is to

6 African Development Bank, '2009 Country Policy and Institutional Assessments Questionnaire', (2009), www. afdb.org/fileadmin/uploads/afdb/Documents/Project-and-Operations/2009\%20CPIA\%2oQuestionnaire\%20 \%28English\%29\%20\%28Rev\%20\%29\%20-\%20Oct\%2019\%202009-1.pdf (accessed 26 August 2013); Finn Tarp, 'Aid and Development', Swedish Economic Policy Review 13 (2006), 9-61.

7 Over time the CPIA has changed slightly. It used to contain 20 indicators. See, for instance, Ravi Kanbur, 'Reforming the Formula: A Modest Proposal for Introducing Development Outcomes in IDA Allocation Procedures', Cornell University Working Paper (2005), www.arts.cornell.edu/poverty/kanbur/IDAForm.pdf (accessed 20 June 2013). Other changes to the formula include the fact that capital account convertability and privatization are no longer included in the guidelines for good policy; see Adam Minson, 'Dialogue on the CPIA and Aid Allocation', The Initiative for Policy Dialogue Working Paper Series, (2007), Ms.

8 OECD, 'Aid Statistics', (2010), www.oecd.org/dac/stats/ (accessed 15 July 2013). There are many different measures of poverty and I discuss some different proxies below. For some work on standard measures of income poverty, see Subramanian (2002); Nicole Hassoun and Subbu Subramanian, 'On Some Problems of Variable Population Poverty Comparisons', UNU WIDER Working Paper 2010/71 (2010), http://www.wider.unu.edu/publications/workingpapers/2010/en_GB/wp2010-71/(accessed 13 May 2013).

9 Unlike other 'aid', ODA does not include military aid. Rather ODA primarily includes grants and loans to developing countries. Here is the official definition: "Flows of official financing administered with the promotion of the economic development and welfare of developing countries as the main objective, and which are concessional in character with a grant element of at least 25 percent (using a fixed 10 percent rate of discount). By convention, ODA flows comprise contributions of donor government agencies, at all levels, to developing countries ("bilateral ODA") and to multilateral institutions. ODA receipts comprise disbursements by bilateral donors and multilateral institutions. Lending by export credit agencies-with the pure purpose of export promotion-is excluded') International Monetary Fund [IMF], 'External Debt Statistics: Guide for Compilers and Users - Appendix III - Glossary', [2003], www.imf.org/external/ pubs/ft/eds/Eng/Guide/index.htm [accessed 19 March 2013]). 
reduce poverty, it is important to consider whether or not it is a good idea to make aid conditional on good institutional quality.

Perhaps one could argue that the debate about making aid conditional on good institutional quality is purely academic for one of two reasons. First, even those international institutions and states that use a metric for allocating aid that takes into account institutional quality often fail to actually implement these rules consistently. The IDA, for instance, makes many exceptions - e.g., it gives more aid to small island states and post-conflict countries than they should receive on its metric. Second, if aid were allocated according to these metrics, many international institutions and states giving aid would actually give more aid to poorer countries.

The graph below illustrates how disbursements according to the IDA allocation formula would be much more highly correlated with other proxies for poverty than actual IDA allocations or ODA in general. ${ }^{10}$

\section{Correlation Matrix}

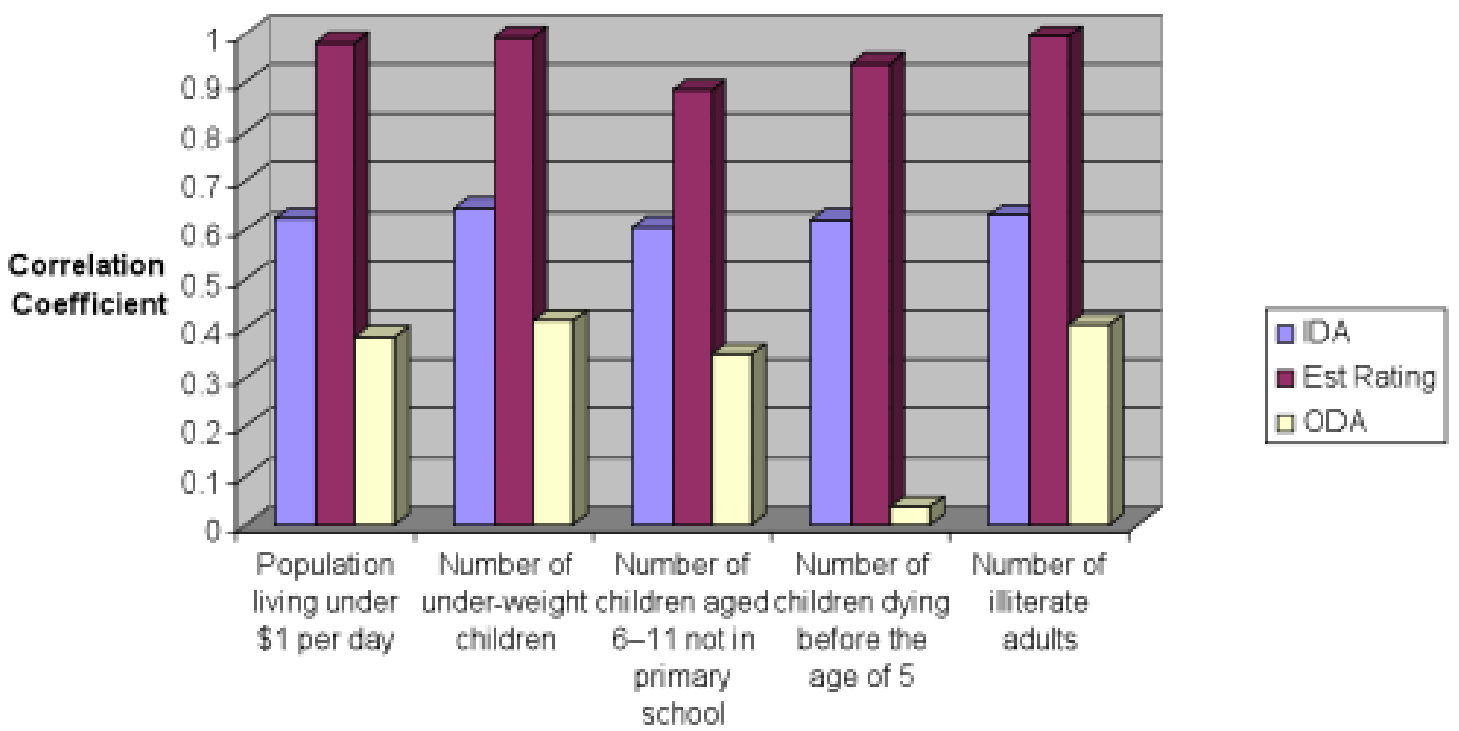

Figure 1: Author's Calculations of Correlation between IDA rule, IDA allocation, ODA allocation, and Other Proxies for Poverty

10 The official definition of ODA is 'Grants or loans to countries and territories on the DAC List of ODA Recipients (developing countries) and to multilateral agencies which are: (a) undertaken by the official sector; (b) with promotion of economic development and welfare as the main objective; (c) at concessional financial terms (if a loan, having a grant element of at least 25 percent). In addition to financial flows, technical co-operation is included in aid. Grants, loans and credits for military purposes are excluded. Transfer payments to private individuals (e.g., pensions, reparations or insurance payouts) are in general not counted') OECD, 'Official Development Assistance - Definition and Coverage', [2013], http://www.oecd.org/dac/stats/officialdevelopmentassistancedefinitionandcoverage.htm [accessed 25 April 2013]). 
If the IDA's rule for allocating aid were actually implemented, it would ensure that aid goes to poorer countries on many metrics for poverty. Looking at a sample of 35 countries for which data is easily available, it is clear that estimated disbursements according to the IDA allocation rule would be highly correlated with child mortality, malnutrition, lack of primary education, and adult illiteracy rates as well as poverty rates. ${ }^{11}$

It is not clear, however, that allocation rules' justifications are unimportant - the IDA's rule, for instance, does seem to govern the disbursement of much international aid. Moreover, the correlation between poverty (etc.) and disbursements according to allocation rules in no way justifies these rules. Giving aid in these ways may still do little to alleviate poverty or secure international development. There may be other rules that would be better for achieving this objective. Just like giving money to someone who is sick or who is doing poorly in school might not be the best way to help them get better or improve their grades, giving aid to poor countries may not be the best way to help them reduce poverty. At least this correlation cannot justify any kind of institutionalism. ${ }^{12}$ So it is worth seeing if, taking into account the incentives aid creates, a case can be made for making aid conditional on good institutional quality.

The rest of this paper suggests that, insofar as aid is supposed to relieve poverty, there is little reason to believe we should make aid conditional on good institutional quality. The next section considers the main theoretical argument put forward for using aid allocation metrics that put a lot of emphasis on institutional quality. The fourth section turns to some of the evidence regarding the impact on poverty of making aid conditional on good institutional quality.

\section{Theoretical Arguments for Conditionality: Moral Hazard}

Perhaps the best theoretical argument for making aid conditional on good institutional quality is the moral hazard argument. There are many different version of the moral hazard argument that posit different mechanisms by which giving aid on the basis of poverty alone creates potentially counter-productive incentives. It is only necessary to consider, however, a version that the IDA seems to embrace when it says: 'While it is natural to focus on how the allocation formula distributes aid across poor countries, it should be kept in mind that it also affects

11 Author's calculations using the 2004 IDA disbursement formula and looking just at the subset of countries for which data was available from the following sources: Bob Baulch, 'Aid Distribution and the MDGs', World Development 34/6 (2006), 933-50; United Nations Development Programme, 'Human Development Report 2010', (2010), http://hdr. undp.org/sites/default/files/reports/270/hdr_2010_en_complete_reprint.pdf (accessed 15 May 2013).

12 Moreover, this correlation may not be enough to justify any of these rules. Giving to the poorest countries, on any of these measures, might not be the best way to reduce poverty for reasons other than the idea that we have to take into account institutional quality to reduce poverty. 
how poor countries are treated over time. The negative coefficient on per capita GNI (Gross National Income) is essentially a tax on growth'. ${ }^{13}$ The problem this paper will suggest moral hazard arguments have is quite general - empirical evidence is necessary to support their claims about incentives.

In the moral hazard argument at issue, the main claim is not that if we give to countries that are poor, simply because they are poor, rulers will keep their countries poor. The claim is that if we give to countries that are poor, simply because they are poor, we create an incentive for rulers to keep their countries poor. An incentive, at least as most economists use the term, just provides a reason for action. An incentive is like a reward or penalty. Rewards or penalties may or may not be efficacious. Sometimes incentives do not work. Nevertheless, many incentives have motivational force. The version of the moral hazard argument above says that if we give to countries that are poor, simply because they are poor, we give rulers a reason to keep their countries poor - they can get more aid. So we should not just give to poor countries, we should instead give to poor countries that have good policies.

Consider an analogy that illustrates the problem with this argument - a variation of philosopher Peter Singer's famous pond case. Suppose that, on your way to work, you see a small child is drowning in a pond. You can save the child by a process that involves giving the child's mother one hundred dollars. Even though it will cost you something to do so, if no one else can help the child and the child will otherwise drown, it is clear that you should save the child. Some have pointed out that if you save the child, you create incentives for mothers of small children to throw their children into ponds. The proper reply to this kind of case is that there is no reason to think other mothers (generally) will throw their children in ponds for one hundred dollars even in places where one hundred dollars is a lot of money. Sometimes, we should (simply) aim to ameliorate poverty even if we create bad incentives in the process.

The moral hazard argument may not always be dismissed so easily. In some cases, there may be reason to think many mothers will do things to harm their children if we create incentives for them to do so. After all, some parents probably do maim their children so as to make them better beggars. ${ }^{14}$ It is less clear that this is because people will help those who are maimed. This may not

13 IDA, 'IDA 14: IDA's Performance Based Allocation', (2004), http://siteresources.worldbank.org/IDA/Resources/ PBAIDA14.pdf (accessed 7 June 2013), p. 7. The IDA actually tries to give poverty some weight in its allocation rule in this way but the general point is that if we give to poorer countries aid, it will be negatively correlated with growth and thus create a disincentive for growth. For criticism of the IDA's attempt to take into account poverty in the way that it does, see Nicole Hassoun, 'World Bank Rules for Aid Allocation: Moral Hazard?' in Helen Stacy and Win-chiat Lee (eds.), Economic Justice (Dordrecht: Springer, 2012b), 221-41.

14 The moral import of this observation is less clear. 
be the best explanation of why mothers might harm their children. A better explanation is that mothers maim their children only because they do not have a better means for helping their families survive.

In any case, the claim that we should not create incentives for some to keep others in poverty requires defense. Consider an expansion of the (first part of the relevant version of) the moral hazard argument:

P1) If we give to countries that are poor, simply because they are poor, we create an incentive for their rulers to keep them poor.

P2) We should not create an incentive for rulers to keep their countries poor.

C) We should not give to countries that are poor, simply because they are poor.

The complaint is that we need some reason to accept the second premise, for it is not always true. Rulers may not act on the incentive aid creates. Giving to countries with good institutions may not increase growth or spur poverty reduction.

More generally, we may be wrong about the efficacy of any posited incentive effect. Other incentive effects may be present and counter the posited effect or the posited effect may fail to generate action. Consider an example from a different domain. Many people believe that decreasing what people are paid gives them an incentive to work less hard. Few seem to recognize, however, that decreasing what people are paid also gives them an incentive to work harder (to make up for lost income). ${ }^{15}$ If some people need very little money (e.g., because they are primarily sustenance farmers), decreasing what they are paid may not influence their behavior at all.

Another problem with many versions of the moral hazard argument is this: Even if aiding on the basis of poverty alone creates some efficacious incentives for rulers to keep their countries poor, we may still have to aid on the basis of poverty alone in some circumstances. Suppose that some countries will not escape poverty on their own and aid may do them very little good. Their leaders may keep them poor in order to receive more aid. Suppose, further, that there is no other way to aid. It may, for instance, be impossible to tell which countries will continue to support themselves after receiving aid and which will remain poor. Further, there may be very few countries that will remain poor and many that will escape poverty permanently. In this kind of case, it is not clearly acceptable

15 For an exception, see Robert Goodin, Reasons for Welfare: The Political Theory of the Welfare State (Princeton University Press: Princeton, 1988). 
to stop giving aid. We may have to give aid even if aid creates some efficacious incentives for some rulers to keep their countries poor.

Nevertheless, there may be something important underlying the moral hazard argument. Consider just one revised version of this argument that avoids the problems outlined above: Giving on the basis of poverty alone creates an efficacious incentive for rulers to keep their countries poor. When we justifiably have some concern for how much poverty we alleviate (etc.), other criteria should enter into our decisions about how to aid. ${ }^{16}$ This argument is much more promising than the original moral hazard argument because it appeals only to efficacious incentive effects. Further, it does not rely on the controversial claim that we need never aid desperately poor countries when some will remain poor because of the incentives aid creates.

Even the revised version of the moral hazard argument gives nothing like the kind of justification necessary for distributing aid only to countries with good institutional quality. For the revised version of the moral hazard argument to be well-justified, the premise that aiding on the basis of poverty alone creates an efficacious incentive for rulers to keep their countries poor requires empirical defense. ${ }^{17}$

Finally, even if some of the negative incentives aid creates do drive behavior, what we should do about that is still an open question. Even if giving aid to poor

16 This may be so, for instance, if resources are so scarce that we are unable to eliminate poverty and do all of the other things that matter. This is not clearly the case in the actual world, however. For, (1) we give very little aid globally and (2) we know a lot about what makes aid work. It is well-known that most countries fall far short of the target of .7 percent of GDP in foreign aid (OECD, 'Development Aid at its Highest Level Ever in 2008', [2008], www.oecd.org/do cument/35/o,3343,en_2649_34487_42458595_1_1_1_1,oo.html [accessed on 28 June 2013]). On average, citizens in OECD-DAC countries gave $\$ 68$ in 2002 (OECD [2004] cited in Tarp [2006], p. 14). Furthermore, there is a lot of good evidence that some aid works. There are many experimental and quasi-experimental evaluations of health and education programs, for instance, that demonstrate their success. There are also good examples of agricultural support, microfinance, school voucher, scholarship, and de-worming programs. See Nava Ashraf, Dean Karlan, and Wesley Yin, 'Female Empowerment: Impact of a Commitment Savings Product in the Philippines', World Development, 38/3 (2010), 333-344; Robert Cassen, Does Aid Work? (Oxford: Clarendon Press, 1986); Jonathan Isham, Deepa Narayan, and Lant Pritchett, 'Does Participation Improve Project Performance: Establishing Causality with Subjective Data', The World Bank Economic Review 9/2 (1995), 175-200; Al Kehler, 'When Will Ethiopia Stop Asking for Food Aid?', in Humanitarian Policy Group (ed.), Humanitarian Exchange. Humanitarian Policy Group No. 27 (London: Overseas Development Institute, 2004), 22-4; Esther Duflo, Rachel Glennerster, and Michael Kremer, 'Using Randomization in Development Economics Research: A Toolkit', Center for Economic Policy Research Working Paper 6059 (2007). Many of these programs have been successfully replicated and scaled up (Duflo et al. [2007]; Hassan Zaman, 'Poverty and BRAC's Microcredit Programme: Exploring Some Linkages', BRAC Working Paper Number 18 [1997]; Jonathan Morduch, 'Does Microfinance Really Help the Poor? New Evidence from Flagship Programs in Bangladesh', Harvard University Department of Economics and HIID Working Paper [1998] http://www.cgdev.org/doc/RM/ Morduch\%201998,\%20Does\%2oMicrofinance\%20Really\%2oHelp\%2othe\%2oPoor--New\%2oEvidence\%2O from\%20Flagship\%2oPrograms\%20in\%2oBangladesh.pdf [accessed 16 July 2013]; Mark Pitt, 'Reply to Jonathan Morduch's 'Does Microfinance Really Help the Poor? New Evidence from Flagship Programs in Bangladesh', Ms., http://www.brown.edu/research/projects/pitt/sites/brown.edu.research.projects.pitt/files/uploads/reply_o.pdf [accessed 20 August 2013]). Though it may not be easy to do so, it is clearly possible to create such programs.

17 There may be other arguments for considering other factors besides development or poverty in aid allocation. We might be concerned, for instance, about how fast we can alleviate poverty. This paper will not explore other possibilities. See, however, Deen Chatterjee (ed.), The Ethics of Assistance (Cambridge: Cambridge University Press, 2004); Hassoun and Subramanian (2010). 
countries on the basis of poverty alone creates an efficacious incentive for their rulers to keep them poor and concern with how much poverty we alleviate (etc.) is justified, it does not follow that we should give to those countries with good institutions. For it is possible that giving to countries with good institutions would be no better, or even worse, for the poor than giving on the basis of poverty alone. It is time to turn to the empirical evidence for the conclusion that institutional quality matters. If it is not sustainable, there is reason to endorse a different theoretical framework in the search for reflective equilibrium between theory and practice. Before considering this evidence, it is worth noting that the problem with the moral hazard argument may be a general problem for theoretical economic arguments based on posited incentive effects. Such arguments require empirical substantiation. ${ }^{18}$

\section{The Empirical Evidence and Critique}

Before considering more sophisticated empirical arguments, consider why we cannot conclude that we should make aid conditional on countries having good institutions because institutions are good for poverty reduction. ${ }^{19}$ Most of the literature on the importance of institutional quality focuses on establishing that good institutions foster growth. ${ }^{20}$ But we cannot rely on estimates of how much growth, in general, reduces poverty to bridge the gap in figuring out how institutions impact poverty (even if they increase growth). Not all causes of growth will reduce poverty by the same amount - some may even increase poverty. ${ }^{21}$

18 Some argue that this requires some previously substantiated theoretical framework. See for instance,' Angus Deaton, 'Instruments of Development: Randomization in the Tropics, and the Search for the Elusive Keys to Economic Development', NBER Working Paper 14690 (2009), www.econ.uiuc.edu/ roger/courses/574/readings/Deaton_ Instruments\%20of\%2odevelopment.pdf (accessed 16 April 2013).

19 For some seminal work in New Institutional Economics see Douglass North, Institutions, Institutional Change and Economic Performance (Cambridge: Cambridge University Press, 1990). In this book North argues that institutions are incredibly important for international development as they help create order and reduce transaction costs. However, he provides no empirical evidence to make his case. North instead surveys the history of economic development in several countries and gives informal game-theoretic arguments. Although North's article opened the door to empirical research on this important topic, it does little on its own to establish his empirical conclusions about the importance of goods institutions.

20 One key paper supporting the institutional thesis popularized, in part, by Daren Acemoglu and James Robinson's book Why Nations Fail (New York: Crown Business Publishing, 2012), is Daron Acemoglu, Simon Johnson, and James Robinson, 'The Colonial Origins of Comparative Development', The American Economic Review 91 (2001), 1369-401. In this paper, Acemoglu et al. implemented (a now widely used method) of dealing with what economists call an 'endogeneity' problem - roughly, the problem that arises when we do not take into account the impact of reverse causation. One way to deal with this problem is to introduce an 'instrument' - something that is correlated with the right-hand side variable (the hypothesized causal factor - in this case institutional quality) - but should be independent of the left-hand side variable (that is of interest - here, growth). In order to identify the instrument for the quality of institutions, Acemoglu et al. look at differences in settler mortality during colonial time. It seems, however, that more than a modicum of faith is necessary to accept arguments based on this instrument for institutional quality. Acemoglu et al.'s instrument might be good for colonialism (or successful colonialism) but it does not clearly capture any kind of institutional quality.

21 Fernando Teson, 'When Philosophers Misdiagnose', Analysis 74/1 (2014), 107-18. There may also be another problem with the literature on institutional quality. The proposition that 'institutions matter' is compelling (who would doubt this? - especially if, as Teson suggests, '[g]ood governance may be roughly defined as the traditions and institutions by which authority in a country is exercised to the benefit of its citizens') (Teson [2014], p. 112). Nevertheless, when one pays attention to the details of the regressions in economists' empirical studies, it is clear that they contain many different and inconsistent (implicit) definitions of institutional quality. 
A few papers do look at the impact of institutional quality on poverty specifically. ${ }^{22}$ However, the evidence that good institutions are good for poverty reduction may have some problems in dealing with reverse causality. ${ }^{23}$

Moreover, even if the claim that good institutions are good for poverty reduction is correct, further evidence is necessary to establish that aiding countries with good institutions will ameliorate poverty. Even if aid improves institutional quality, some causes of institutional improvement may not contribute to poverty relief. Alternately, aid may not improve, it may even destroy, good institutions. ${ }^{24}$ Mathias Risse might be right when he says that 'the sources of wealth rest in [domestic] institutional quality... . While foreigners can destroy institutions, they can often do little to help build them'. ${ }^{25}$ The general form of argument $-\mathrm{x}$ reduces poverty so we should give to countries with $\mathrm{x}$ - is not a good one. It is important to consider whether countries, or international institutions, offering aid might do better to target it in other ways. ${ }^{26}$ We need to know whether aid has more impact in countries with good institutional quality.

There is a large body of empirical evidence that might support the claim that 'among low-income countries, large-scale financial aid has more impact in an environment of sound institutions and policies' ${ }^{27}$ Perhaps the seminal article on the topic is 'Aid, Policies, and Growth' (first put out as a working paper in 1997) by Burnside and Dollar. This paper argues that aid works only in countries with 'good policies' using a measure of policy quality that contains budget surplus, trade openness and inflation weighted by their correlation with growth rates. ${ }^{28}$

22 See, for instance, Omar Azfar, 'Institutions and Poverty Reduction', Center for Institutional Reform and the Informal Sector (IRIS), University of Maryland, College Park, (2005), http://siteresources.worldbank.org/INTPGI/ Resources/342674-1115051862644/Institutions8.pdf (accessed 23 April 2013).

23 In the paper cited above, for instance, institutional quality is not a significant predictor of growth on the standard instrument for institutional quality (moreover, I do not find this instrumentation strategy compelling - see discussion in notes below).

24 Aid may help countries with bad institutions improve their institutions and reduce poverty

25 Mathias Risse, 'Do We Owe the Poor Assistance or Rectification?' Ethics \& International Affairs 19/1 (2005), 9-18.

26 Even if the institutionalist thesis is true, it is so vague as to be unhelpful. It is not clear what components of institutional quality as measured by the CPIA index, for instance, are contributing to aid's success (see Dani Rodrik, 'Getting Institutions Right', [2004], http://www.cesifo-group.de/pls/guestci/download/CESifo+DICE+Report+2004/ CESifo+DICE+Report+2/2004/dicereport204-forum2.pdf [accessed April 23 2013]. Very different institutional systems can also receive high ratings on different indexes. Even a legal system based on private property is not necessary for high ratings (e.g., China seems to do pretty well on some ratings). Some commentators argue against having a single formula for aid disbursement at all - context matters, there is no one-size fits all approach. Perhaps we should look for contingent correlations between local economic conditions and success (Rodrik [2004], p. 9). Still, there should be a point to saying 'institutions rule'.

27 IDA (2004), p. 6; Craig Burnside and David Dollar, 'Aid, Policies, and Growth', American Economic Review, 90/4 (2000), 847-68; Craig Burnside and David Dollar, 'Aid, Policies, and Growth: Revisiting the Evidence', World Bank Policy Research Working Paper 2834 (2004); David Dollar and Victoria Levin, 'Increasing selectivity of foreign aid, 1984-2002', World Bank Policy Research Working Paper 3299 (2004); Paul Collier and David Dollar, 'Aid Allocation and Poverty Reduction', European Economic Review 46/8 (2002), 1475-500.

28 Burnside and Dollar (2000). This research was also picked up by the World Bank report by David Dollar and Lant Pritchett, 'Assessing Aid- What Works, What Doesn't, and Why', (1998), http://documents.worldbank.org/curated/ en/1998/11/43889o/assessing-aid-works-doesnt (accessed 5 June 2013) and Collier and Dollar (2002) have taken on leadership roles within the Bank's research department, greatly influencing public opinion and probably economic policy (William Easterly, 'How the Millennium Development Goals are Unfair to Africa', World Development 37/1 [2009], 26-35). 
Collier and Dollar and Burnside and Dollar extended this work using other measures of institutional quality including the CPIA index. ${ }^{29}$

Unfortunately, the Burnside and Dollar study has been roundly criticized, and its successors suffer from many of the same problems. ${ }^{30}$ These problems undermine the evidence that distributing aid to countries on the basis of institutional quality is an effective way to increase growth rates. Many researchers have had trouble replicating the results in Burnside and Dollar's study and its successors. ${ }^{31}$ The results are, at least, quite fragile; they depend greatly on the particular theoretical assumptions (model specification) and data used. ${ }^{32}$ The studies at issue may well have endogeniety problems and aid may not have a linear relationship to growth (though the studies suppose otherwise). ${ }^{33}$ Some of the studies depend on a few crucial (country and year) observations. ${ }^{34}$

Some researchers also question the general thesis that aid is more effective in good institutional environments. Some suggest that good institutions are not a precondition for aid to work, though good institutions increase aid's impact on growth. ${ }^{35}$ Others argue that features of countries besides their institutional quality, like climate, may explain why aid works in some places but not others. ${ }^{36}$ Some even find that good institutions may hinder aid's effectiveness. ${ }^{37}$

Both Burnside and Dollar and Dollar and Levin try to defend the evidence in favor of aiding countries with good institutions. ${ }^{38}$ They point out that 'common to many of these criticisms is a change in specification, either in terms of estimation technique, or in terms of which variables are included in the regression'. 39 But one complaint about Burnside, Dollar, and Levin's studies was precisely that

29 Collier and Dollar (2002) and Craig Burnside and David Dollar, 'Aid, Policies, and Growth: Revisiting the Evidence', World Bank, Policy Research Working Paper No. 2834 (2004). There are many worries about this and the other measures of institutional quality researchers use, but this paper will set aside any problems with the measures of institutional quality in the studies for now. For discussion of the CPIA index, in particular, see Hassoun (2012b).

30 Robert Lensink and Howard White, 'Are There Negative Returns to Aid?', (1999), http://som.eldoc.ub.rug.nl/FILES/ reports/1995-1999/themeE/1999/99E60/99e60.pdf (accessed 20 July 2013); Carl-Johan Dalgaard and Henrik Hansen, 'On Aid, Growth, and Good Policies', CREDIT Research Paper oo/17 (2000), http://www.iese.ac.mz/lib/ saber/ead_53.pdf (accessed 17 June 2013); Carl-Johan Dalgaard, Henrik Hansen, and Finn Tarp, 'On The Empirics of Foreign Aid and Growth', The Economic Journal 114 (2004), 191-216.

31 Lensink and White (1999); Shuans Lu and Rati Ram, 'Foreign Aid, Government Policies, and Economic Growth: Further Evidence from Cross-Country Panel Data for 1970-1993’, International Economics 54/1 (2001), 15-29.

$32 \mathrm{Lu}$ and Ram (2001); Dalgaard and Hansen (2000).

33 Deaton (2009); Dalgaard and Hansen (2000); Channing Arndt, Sam Jones and Finn Tarp, 'Aid and Growth', UNUWIDER Discussion Paper 2009/05 (2009).

34 William Easterly, Ross Levine, and David Roodman, 'New Data, New Doubts: Revisiting “Aid, Policies, and Growth”, Center for Global Development Working Paper Number 26, www.cgdev.org/sites/default/files/2764_file_cgd_ wp026.pdf (accessed 17 August 2013).

35 Dalgaard and Hansen (2000).

36 Dalgaard, Hansen, and Tarp (2004).

37 Dalgaard and Hansen (2000).

38 Ibid.

39 Dollar and Levin (2004), p. 2; Burnside and Dollar (2004), p. 6. 
they use the wrong theoretical specification. As to data sources, Dollar and Levin admit that it was, for a long time, literally impossible for other researchers to access their data. ${ }^{40}$ What Dollar et al. do not mention is that this is because the World Bank's research department, in which Dollar and Collier have both taken leadership positions, had not released it. Furthermore, even when researchers were eventually given access to the original data, they were unable to replicate the results. ${ }^{41}$ So there is little reason to believe these studies' conclusions.

An equally important critique, however, is that the main studies supporting Burnside and Dollar's results use GDP per capita as a measure of poverty. At best there is a large gap between the studies' results and the claim that a metric for allocating aid that makes aid conditional on good institutional quality is justified because it reduces poverty. Consider Dollar and Collier's argument that increasing the weight given to poorer countries in the IDA's formula will reduce aid's effectiveness in ameliorating poverty. They suggest that the 'poverty efficient' allocation of aid rises with GNI per capita to about $\$ 800$ in part because relatively richer poor countries are better able to absorb aid. ${ }^{42}$ However, to estimate the 'poverty efficient' allocation, the authors of this study - Paul Collier and David Dollar - assume that growth will reduce poverty by a certain amount and that there is a set budget for reducing poverty. Neither of these claims is well justified. They simply assume, for instance, that the effect of aid is distributionally neutral and then adopt an estimate of the poverty elasticity of growth given mean income based on a few research papers. ${ }^{43}$ The papers they rely upon look at the general impact of growth on poverty, however, not on the impact of aid-induced growth on poverty which, as noted above, may be a quite different matter. Although the debate will surely continue, the evidence that making aid to countries conditional on their having good institutions will better reduce poverty is not compelling.

\section{Conclusion}

This paper provided a critical introduction to some of the literature on institutional quality and international development. It looked, in particular, at an argument for the conclusion that making aid conditional on good institutional quality will promote development by reducing poverty. It suggested that there is little evidence that this kind of conditionality is good for the poor. Even if institutional quality turns out to be an important determinant of aid's efficacy, however, many other things besides good institutions may contribute to aid's ability to reduce poverty. ${ }^{44}$ Moreover, even though it would be incredibly surprising if good

40 Dollar and Levin (2004).

41 Dalgaard and Hansen (2000).

42 Collier and Dollar (2002).

43 Ibid., pp. 17-8.

44 For instance, see Jeffrey Sachs, Andrew Mellinger, and John Gallup, 'The Geography of Poverty and Wealth', Scientific American 284 (2001), 70-5. 
institutions - under some definition - were not important for good development, there are strong arguments that other things matter as well. So the take-home lesson is not that good institutions do not matter - but just that we need to think carefully about how we can better make the case that they matter. We should also look closely at the ways that good institutions do and do not matter in trying to promote international development.

More generally, this paper aimed to illustrate a new way that philosophers might contribute to the philosophy of economics. Philosophers of economics have so far focused on the foundations of welfare economics - evaluating the coherence and plausibility of the assumptions underlying much theoretical work in the discipline. There are, however, many important discussions in economics' sub-disciplines, including development economics, to which philosophers can fruitfully contribute. ${ }^{45}$

Prof. Nicole Hassoun

Department of Philosophy

Binghamton University

email:nhassoun@binghamton.edu

\section{- the global justicenetwork}

45 This paper draws largely on my paper 'World Bank Rules for Aid Allocation' presented at the AMINTAPHIL conference on economic justice and subsequently published in their conference proceedings. I would like to thank the editors for permission to publish a revised version of the paper here as well as those who kindly provided comments on drafts of that paper. 


\section{Appendix: The IDA's Formula for Aid Allocation and the CPIA Index}

Very roughly, ${ }^{46}$ the IDA's Formula for Aid Allocation is this:

$$
\mathrm{f}\left(\mathrm{PR}^{2.0}, \mathrm{GNIPC}^{-0.125}\right)
$$

GNIPC stands for Gross National Product Per Capita. The IDA gives less weight to GNIPC as it rises so that each increment of income yields less aid. ${ }^{47} \mathrm{PR}$ stands for Performance Rating and the Country Policy and Institutional Assessment index (CPIA) makes up 80\% of the PR. The Annual Review of Portfolio Performance (ARPP), the Bank's rating of projects in a country, makes up the remaining 20\%. ${ }^{48}$ This sum is then scaled by a measure of countries' governance quality. This measure is taken from the six governance criteria in the CPIA and one in the ARPP (weighted equally, divided by $3.5^{49}$ and raised to the power of 1.5 ). In effect, governance gets a lot of weight in the formula. There are also many exceptions. ${ }^{50}$

Although the exact formula changes over time, the IDA14 formula was:

Allocation Country i (3-year) = SDR3.3 million + Performance-Based Allocation i (PBA i) where:

$$
\begin{aligned}
& \text { PBA } \mathrm{i}=\frac{\text { (IDA rating i) } 2 \times \text { Population } \mathrm{i} \times(\mathrm{GNI} / \text { cap i)-.125 }}{\Sigma i=1} \times \text { Envelope } \\
& \begin{array}{l}
\text { (i) IDA Rating Country } \mathrm{i}=(\mathrm{x} \text { ( } 0.8 \times \text { CPIA } \mathrm{i}+0.2 \mathrm{x} \text { ARPP } \mathrm{i}) \times \mathrm{x} \text { Govfact } \mathrm{i} \\
\text { (i) }
\end{array} \\
& \text { (ii) Governance Factor } \mathrm{i}=\text { (average rating of } 6 \text { governance criteria } \\
& \text { i / 3.5) } 1.5
\end{aligned}
$$

\footnotetext{
46 The IDA's formula continues to evolve over time. See, for instance, IDA, 'IDA 15: IDA's Performance Based Allocation', (2007a), www.siteresources.worldbank.org/IDA/Resources/Seminar\%20PDFs/73449-1172525976405/34928661172527584498/PBAformula.pdf (accessed 19 July 2013); IDA, 'IDA 15: Selectivity and Performance', (2007b), www. siteresources.worldbank.org/IDA/Resources/Seminar\%2OPDFs/73449-1172525976405/3492866-1172527584498/ PBAEffectiveness.pdf (accessed 23 July 2013).

47 Kanbur (2005), p. 11

48 Jeff Powell, 'The World Bank Policy Scorecard: The New Conditionality?' Bretton Woods Project, (2004), www. brettonwoodsproject.org/2004/11/art-84455/ (accessed 26 September 2013).

49 CPIA scores for each criteria are between 1 (low) and 6 (high), 3.5 is the mid-point.

50 Post-conflict countries get some precedence for IDA assistance but this is not reflected in the formula itself. Since there is a cap on how much aid countries can receive, there is also a bias in favor of small countries not reflected in the formula. A few years ago the Bank reported that 'sixty-two percent of IDA 14 resources will be allocated using the formula; another 14 percent go to the capped wealthier countries (India, Indonesia and Pakistan); 10 percent go to post-conflict countries and 8 percent go to "special purposes" agreed during the replenishment process' (Bretton Woods Project, 'The IDA replenishment', [2007], www.brettonwoodsproject.org/art-552223 [accessed 5 June 2013]). The fact that small countries get more than their proportionate share of assistance (Tarp [2006], p. 26) should probably be questioned, though this paper will not take on this task.

51 IDA (2004).
} 
The CPIA index is based on a questionnaire filled out by World Bank personnel. It contains 16 indicators in four equally weighted groups - structural policies, economic management, public management and institutions, and social inclusion/equity policies. CPIA scores for each criteria are between 1 (low) and 6 (high).

To come up with the ratings, evaluators rate a small number of countries in each region and provide narrative guidelines to country staff who then rate countries on each criterion. The scores are modified by the chief economists in the region. Sector experts review the new scores, and modifications are reviewed by the chief economists again. An arbitration panel resolves disputes. Below are the CPIA Index Rating Categories.

A. Economic management

1. Monetary and exchange rate policy

2. Fiscal policy

3. Debt policy

B. Structural policies

4. Trade

5. Financial sector

6. Business environment

C. Policies for social inclusion

7. Gender

8. Equity of public resource use

9. Building human resources

10. Social protection and labor

11. Policies and institutions for environmental sustainability

D. Public sector management and institutions

12. Property rights and rule-based governance

13. Quality of budgetary and financial management

14. Efficiency and equity of revenue mobilization

15. Quality of public administration

16. Transparency, accountability and corruption in the public sector ${ }^{52}$

Here is some further information about CPIA 'governance criteria' which receive a good deal of weight in the World Bank's analysis of countries' institutional quality:

Property rights and rules-based governance: a good score requires, inter alia, that property rights be protected in 'practice as well as 
theory'; laws and regulations affecting businesses are 'transparent and uniformly applied'; obtaining licences is a small share of the cost of doing business; police force functions well and is accountable.

Quality of budgetary and financial management: assesses extent to which budget is linked to policy priorities in national strategies; effective financial management; timely and accurate fiscal reporting; and clear and balanced assignment of expenditures and revenues to each level of government.

Efficiency of revenue mobilization: a good score requires that 'bulk of revenues' be generated from 'low-distortion' taxes such as sales/ VAT, property, etc.; low import tariffs; tax base is free from arbitrary exemptions.

Quality of public administration: assesses 'policy coordination and responsiveness, service delivery and operational efficiency, merit and ethics, and pay adequacy and management of the wage bill'.

Transparency, accountability and corruption: a good score requires accountability reinforced by audits, inspections and adverse publicity for performance failures; an independent, impartial judiciary; conflict of interest and ethics rules for public servants. ${ }^{53}$ 